\title{
GASTROBRANCHUS CACUS.
}

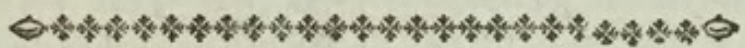

\section{CHARACTER GENERICUS.}

Spiracula duo ventralia.

$$
\text { Bloch. icloth. 12. append. p. } 5^{\circ} .
$$

CHARACTER SPECIFICUS, छC.

GASTROBRANCHUS oculis carens.

$$
\text { Bloch. ichth. 12. append. p. } 5^{1 .}
$$

MYXINE glutinofa.

$$
\begin{aligned}
& \text { Lin. Syft. Nat. p. } 1080 . \\
& \text { Lin. Syf. Nat. Gmel. p. } 3082 . \\
& \text { Muf. Ad. Frid. 1. p. 91.t. 8. f. } 4 \text {. }
\end{aligned}
$$

Myxines glutinofa nomine vermibus adjunxit Linnæus animal in tabula depictum, a Blochio rectius pifcibus annumeratum, inftituto ei novo genere, quod dicitur Gaftrobrancbus. Mirum eft Linnæum aliofque phyficos ab hoc non difcriminaffe Lampetram cæcam Willughbeii; quam quoque repræfentari ab effigie qua exftat in Pennanti Zoologia Britannica exiftimat Blochius, nequaquam vero $\mathrm{Gaf}$ trobranchum noftrum, feu veram Myxinem glutinofam Linnæi. Longum effe Gaftrobranchum feu Myxinem paucas uncias tradunt Linnæus aliique. $\mathrm{E}_{2}$ 
In Mufeo tamen Britannico confpici poffit fpecimen fere æquale mediocri anguillæ; et in celeberrimi Jofephi Bankfii pinacotheca, in qua nempe reponuntur icones animalium auftralium, depingitur Gaftrobranchus communi anguillæ certe non minor. Verifimile eft igitur magnitudine multum variare, et Europeis longe majora effe antarctica fpecimina. Adeo glutine abundat mirum hoc animal, ut aquam marinam gelatam brevi reddat. Generatur in maribus tum feptentrionalibus tum auftralibus. Privatur omnino oculis: quod fortaffe Linnæum aliofque in errorem duxit, quibus nihil differre vifum eft inter hoc et Lampetram cæcam Willughbeii. Lampetræ tamen non defunt prorfus oculi licet minimi fint. Plane igitur conftat genus Myxenem a vermibus debere ablegari; fupra enim vidimus ad pifces referendum effe, ad pifces nempe cartilageos, five nantes Linnæi.

Figura fecunda monftrat partem anticam difiectam et apertam, ut de formatione duplicis feriei dentium, nec non de fimplici dente curvato in medio palati fuperioris melius et commodius poffit inquiri. 


$$
18
$$




\section{GLUTINOUS GASTROBRANCHUS.}

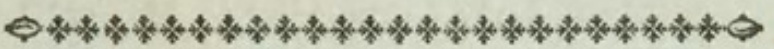

\section{GENERIC CHARACTER.}

Mouth terminal, furnithed with cirri or beards. Teeth in a double pectinated row on each fide: Upper tooth fingle, fharp, in the roof of the mouth.

Body anguilliform, carinated beneath by a foft fin. Two Ventral Spiracula.

SPECIFIC CHARACTER, EंC.

Eel-fhaped GASTROBRANCHUS without eyes.

The Glutinous HAG.

$$
\text { Pennt. Zool. Brit. 4. p. } 33 \text {. }
$$

The HAG-FISH, or Slime-Worm.

Der BLINDFISCH.

$$
\text { Bloch. ichth. t. } 413 \text {. }
$$

The animal which forms the fubject of the prefent plate was by Linnæus ranked amongt the Vermes, under the title of Myxine glutinofa. Dr. Bloch however has with great propriety given it its true rank 
rank amongft Fifhes, and has inftituted for it the genus Gaftrobrancbus. It is remarkable that a very different animal has by Linnæus and others been confounded with it: viz. a fmall fpecies of Petromyzon or Lamprey; (Lampetra cæca. Will. ichth.) The figure alfo in the Britifh Zoology is, according to Dr. Bloch, by no means the Gaftrobranchus, (Myxine glutinofa, Lin.) but the above-mentioned fmall fpecies of Petromyzon. Linnæus and others have alfo defcribed the Gaftrobranchus (Myxine) as feldom exceeding the length of a few inches; yet in the Britifh Mufeum is a fpecimen not lefs than a middle-fized eel : and in a collection of drawings of South-Sea animals in the poffeffion of Sir Jofeph Banks, a figure occurs of the fame animal at leaft as large as a common eel. We may therefore conclude that it varies very greatly in fize, and that the European fpecimens fall far fhort of the Antarctic ones. When placed in a veffel of fea water this fifh foon renders it gelatinous, being of an uncommonly glutinous nature. It is found in the Mediterranean and the northern feas, as well as in thofe of the fouthern hemifphere. It is entirely deftitute of eyes, which feems to have been the reafon of Linnæus and others having confounded it with the Lampetra cæca of Willughby above mentioned, in which fifh however there are eyes, though very fmall ones.

It muft be unneceffary to add that the genus Myxine amongft the Vermes muft be now exploded; the animal belonging, as we have feen, to the divifion of Cartilaginous Fithes, or Nantes of Linnæus. 
The fecond figure reprefents the fore-part of the animal opened, in order to fhew the ftructure and fituation of the double rows of teeth; as well as the fingle curved tooth in the middle of the roof of the mouth. 


\section{$2 \mathrm{BHL}$ Biodiversity Heritage Library}

Shaw, George. 1798. "The Glutinous Gastrobranchus, Gastrobranchus cæcus [PI. 362]." The Naturalist's Miscellany 10(CXII), https://doi.org/10.5962/p.304544.

View This Item Online: https://www.biodiversitylibrary.org/item/276641

DOI: https://doi.org/10.5962/p.304544

Permalink: https://www.biodiversitylibrary.org/partpdf/304544

\section{Holding Institution}

Museums Victoria

\section{Sponsored by}

Atlas of Living Australia

\section{Copyright \& Reuse}

Copyright Status: Public domain. The BHL considers that this work is no longer under copyright protection.

This document was created from content at the Biodiversity Heritage Library, the world's largest open access digital library for biodiversity literature and archives. Visit BHL at https://www.biodiversitylibrary.org. 